\title{
Ernst Haeckel's Radiolarians and Medusa: The influence of his visits to Villefranche on his science and his art
}

\section{Les radiolaires et les méduses d'Ernst Haeckel : influence de ses visites} à Villefranche-sur-mer sur sa science et son art.

\author{
John R. Dolan ${ }^{1}$ \\ ${ }^{1}$ Laboratoire d'Océanographie de Villefranche-sur-Mer
}

ABSTRACT. Early in his long career, Ernst Haeckel (1834 - 1919) twice visited Villefranche-sur-Mer. First, as a student, in 1856 during a sampling trip to Nice, and again in 1864 when sent to Nice by his parents for a change of scenery following the untimely death of his first wife. The two visits appear to have been key events in the development of Haeckel's science and art as they are the beginnings of his studies, first on radiolarians, and then on medusa. During the 1856 visit he observed for the first time living radiolarians, the group of microscopic planktonic protists, the subject of his first monographic work in 1862 that brought him fame at a young age. During the 1864 visit he resided in Villefranche-sur-Mer. There, for the first time, he made detailed observations on the development and morphology of medusa. He subsequently produced monumental monographs on both radiolaria and medusa, e.g., the Challenger Reports, which remain today his major scientific contributions. Haeckel's artistic fame is largely from his Kunstformen der Natur. The book relies heavily on illustrations of both radiolarians and medusa, more so than other groups of organisms, and contains iconic images of medusa and radiolarians, suggesting a major importance in Haeckel's art for the two groups linked closely with Haeckel's visits to Villefranche-sur-Mer.

RÉSUMÉ. Au début de sa longue carrière, Ernst Haeckel (1834 - 1919) s'est rendu deux fois à Villefranche-sur-mer. D'abord en tant qu'étudiant, en 1856, lors d'un voyage d'échantillonnage à Nice, puis de nouveau en 1864, lorsque ses parents l'envoyèrent à Nice pour un dépaysement total à la suite du décès prématuré de sa première femme. Les deux visites semblent avoir été des événements clés dans le développement de la science et de l'art de Haeckel au début de ses études, d'abord sur les radiolaires, puis sur les méduses. Lors de sa visite en 1856, il observa pour la première fois des radiolaires vivants, groupe de protistes planctoniques microscopiques, sujet de son premier travail monographique en 1862 qui le rendit célèbre à un jeune âge. Pendant la visite de 1864, il résida à Villefranche-surmer. II y fit pour la première fois des observations détaillées sur le développement et la morphologie des méduses. II a par la suite produit des monographies monumentales sur les radiolaires et les méduses, par exemple les rapports Challenger, qui demeurent aujourd'hui ses principales contributions scientifiques. La renommée artistique de Haeckel provient en grande partie de son livre "Kunstformen der Natur ». Le livre s'appuie beaucoup sur des illustrations de radiolaires et de méduses, plus que d'autres groupes d'organismes, et contient des images emblématiques de méduses et de radiolaires, suggérant une influence majeure dans l'art de Haeckel pour ces deux groupes, étroitement liée aux visites de Haeckel à Villefranche-sur-mer.

KEYWORDS. history of science, plankton, scientific and artistic voyages, microscopy.

MOTS-CLÉS. histoire des sciences, plancton, voyages scientifiques et artistiques, microscopie.

\section{Backstory/Introduction}

This article grew out of a recent serendipitous discovery. I was searching for an obscure species description by Ernst Haeckel, an important personality in the history of biology. He was a contemporary and staunch advocate of Charles Darwin and is one of the best known and most read zoologists (Egerton 2013). I came across another obscure species description by him, one that surprised me. It was a description of a meduse (a jellyfish), and he called it "Carmarina", the Niçois word for sea meat, a term used by the fisherman of the Nice region for gelatinous plankton caught in their nets. 
Haeckel's use of the word suggested a certain familiarity with both the medusa and the fishermen of the region. Given the date, his striking illustration appeared to be his first published drawing of any medusa. His illustrations of medusa are famous, even iconic. In fact, Haeckel is well known for his detailed studies and magnificent illustrations, primarily of two groups of organisms: radiolarians, microscopic creatures with fabulously intricate skeletons or shells, and the medusa (fig.1).

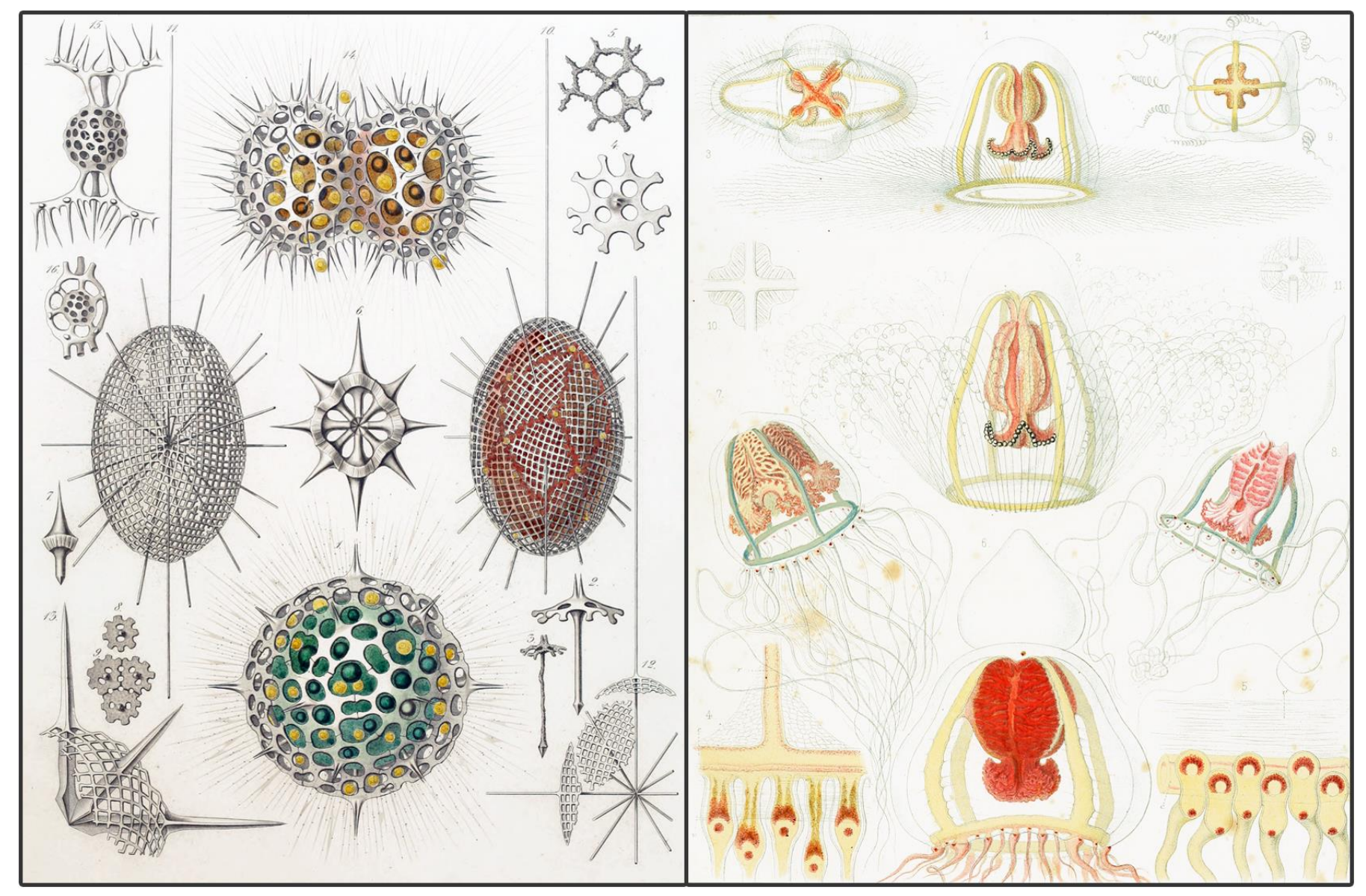

Fig 1. Examples of Haeckel's illustrations of radiolarians (left panel), plate in Haeckel 1862 and medusa (right panel), plate 3 in Haeckel 1879. In actual size, the radiolarians shown are about 1/10 mm in diameter and the medusa shown are about $3 \mathrm{~cm}$ long.

I was familiar with the fact that he first saw living radiolarians when he visited the Bay of Villefranche in 1856 as a young medical student (fig. 2), the veritable start of his studies radiolarians. However, the medusa description suggested his other major obsession, medusa, may have also begun in the Bay of Villefranche with his 1864 stay. The stories presented here, of two relatively short visits, aim to convince you dear reader, that his visits to southern France were key events in the development of Haeckel's science and his art. I hope to convince you that his major scientific and artistic legacies, both of which are considerable, are intimately linked to Villefranche. 


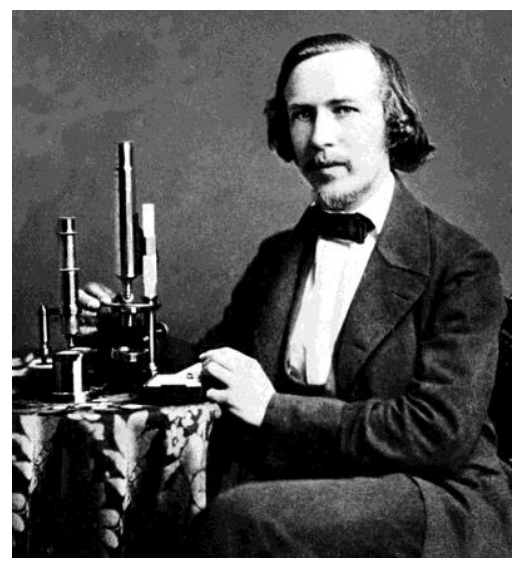

Fig. 2. Ernst Haeckel and his microscopes, ca. 1856, when he was a medical student. His parents bought him his first microscope, a Schiek barrel microscope (on the table at the left), in 1853 and he quickly became very fond of it, calling it "my darling" and "my divine microscope"; he developed the unusual ability to look through the eyepiece with one eye and with the other draw what he saw in the microscope (Otis 2007). Photo courtesy of SLUB Dresden/Deutsch Fotothek.

\section{Haeckel's 1856 Visit}

Ernst Haeckel saw the Bay of Villefranche for the first time during a sampling trip to Nice in the autumn of 1856, at age 22. He had been invited to participate in the expedition by his teacher, Albert Kölliker. Based in Nice, they spent 4 weeks in the region. Many years later, Haeckel stated: "In company with Heinrich Müller and K. Kupffer, we investigated especially the rich pelagic animal life of the beautiful bay of Villafranca. There, for the first time I met those wonderful forms of the pelagic fauna which belong to the classes of the siphonophores, pteropods, and heteropods. I also there first saw living polycyttariia, acanthrometra, and polycystina, those phantasmic forms of radiolaria, in the study of which I spent so many later years". (Haeckel 1893). According to a letter sent to his parents at the time (Haeckel 1856), during their stay they met repeatedly with the Berlin Professor Johannes Müller who was himself sampling along the French Mediterranean coast, in Villefranche, Nice, St. Tropez and Cette (now Sete) for his study of Mediterranean radiolarians published posthumously in 1858 (Müller 1858).

Johannes Müller is credited by Haeckel as the one who initiated him to the study of planktonic organisms, earlier, in 1854 during a trip to Helgoland. Haeckel (1893) states " When at Helgoland, investigating the wonders of the plankton with the microscope, Johannes Müller, pleased with the care and patience with which his zealous students tried to study the charming forms of medusa and ctenophores, spoke to me the ever-memorable words, "There you can do much; and as soon as you have entered into this pelagic wonderland you will see that you cannot leave it." According to Haeckel (1893), in Nice in 1856, Müller stressed to him the particular interest of studying radiolaria as he ".... called my attention to the many and important questions which the natural history of these enigmatical microscopical organisms present.".

Haeckel mentions, in that same letter to his parents (Haeckel 1856), that towards the end of their stay, they used "Müller's fine nets" to collect organisms in the Bay of Villefranche noting that among the catch were the most remarkable Thalassicolla (a group of radiolarians). It was perhaps this outing from Nice that provided the sample containing the radiolarian Haeckel described in his 1862 monograph, Sphaerozoium italicum (Fig. 3), as from his stay in Nice in 1856. It appears to be the first new species of radiolarian he collected. In recent years, the species was collected again from the Bay of Villefranche and molecular data from it used to refine the phylogeny of radiolaria (Bass et al. 2005). 


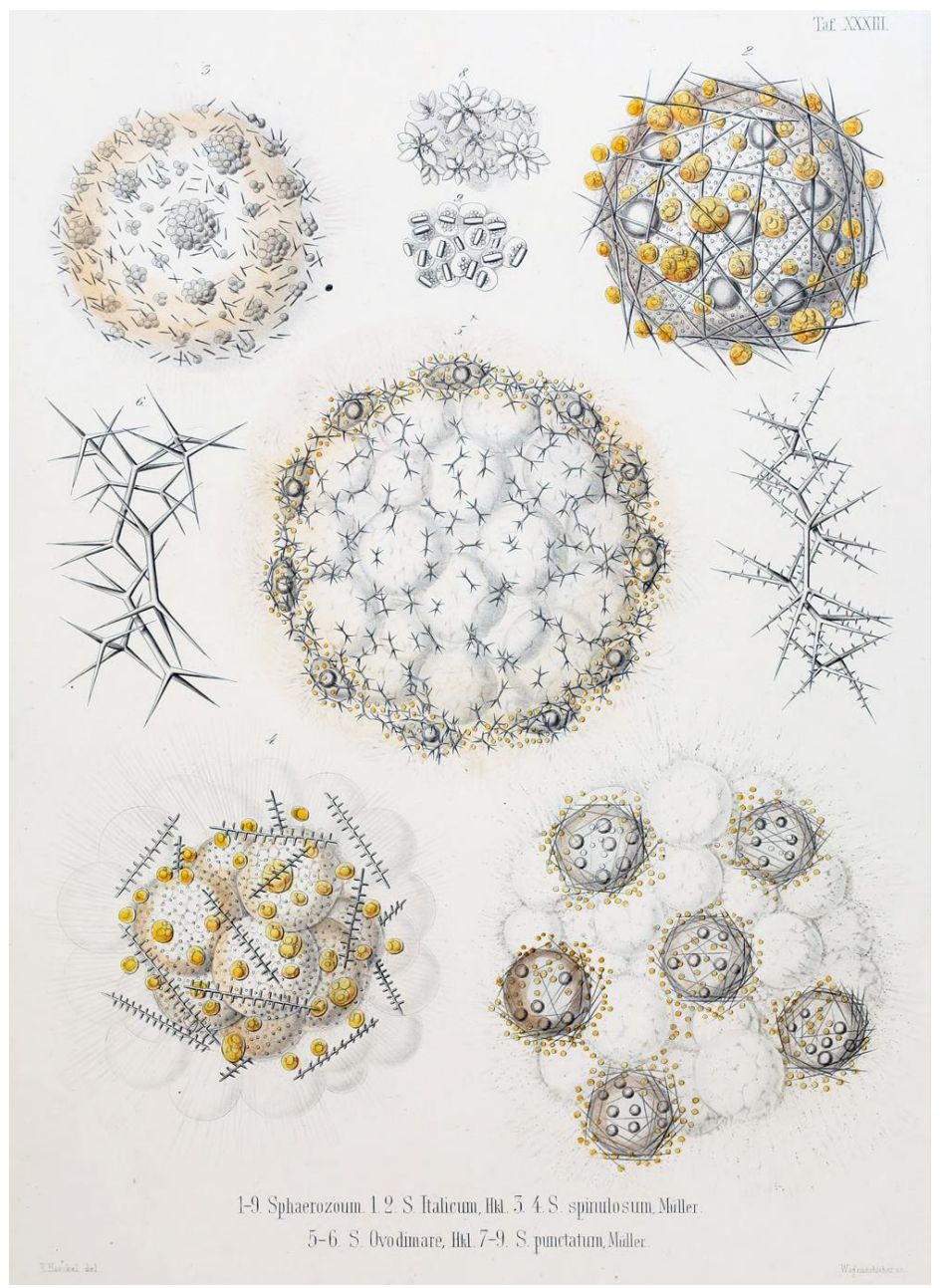

Fig 3. Plate 33 from Haeckel's 1862 monograph Die Radiolarien, showing the radiolarian species first collected during his 1856 visit, Sphaerozoum italicum (figs. 1 \& 2). The diameter of the radiolarian is about $1 / 3 \mathrm{~mm}$.

The 1862 'Die Radiolarien' was Haeckel's first monographic publication (excluding his thesis and habilitation volumes) and he dedicated it to Johannes Müller. The study was largely the result of a long stay in Messina devoted mostly to collecting and examining radiolarians. Haeckel credited Müller's suggestion, made in Nice in 1856, as the motivation for his "spending an entire year in pelagic fishing" (Haeckel 1893). The massive two-volume work earned Haeckel a promotion to "Extraordinary Professor" and the Cothenius medal of the Leopold-Caroline Academy of German Naturalists in 1863. Haeckel sent a copy to Darwin and it is said to have astonished him (Richards 2008).

In subsequent years, Haeckel turned his attention to other groups of organisms and topics. $\mathrm{He}$ returned to studies of radiolarians only in the 1880's as he was asked to exploit the sample gathered during Challenger Expedition. His resulting radiolarian "masterpieces" are the monographs constituting the "Report on the Radiolaria" (Haeckel 1887a,b), totaling over 1700 pages of text and 140 plates. Although Haeckel's taxonomy has been revised, and many species have been found to be synonyms, (e.g. Aita et al. 2009; Lazarus 2014), the work is still regularly cited today (e.g. Biard et al. 2017, Grattepanche et al. 2017, Dolan et al. 2019, Kachovich et al. 2019)

It is speculation to propose that Haeckel may not have studied radiolarians if Kölliker had not invited Haeckel to join his sampling expedition. However, it is not speculation to state that a firm link exists, not least of all in Haeckel's mind, between his 1856 visit to Villefranche and his subsequent work on radiolarians. 


\section{Haeckel's 1864 Visit}

As mentioned above, following the appearance of his monograph on radiolarians, Haeckel was named "Extraordinary Professor" in Jena. This was in June 1862. The financial stability of the new position allowed him to marry Anna Sethe (to whom he had been engaged since 1858) in August of 1862. Unfortunately, the marriage was short-lived. Anna Sethe Haeckel died suddenly in early February of 1864, perhaps of appendicitis. Haeckel was completely devastated by the loss of his wife. Apparently unable to end his grieving, his parents sent him to Nice for a six-week stay in March-April 1864 for a change of scenery (Richards 2008).

From a long letter to his parents (Haeckel 1864a), we know that Haeckel found Nice disagreeable. He quickly moved to Villefranche, profiting from contacts made during his previous visit. He took rooms in Casa Montolivo, describing his host, Abbé Montolivo, as a "marine doctor". Abbé Montolivo, along with Jean Baptiste Vérany, were the Nice naturalists who had provided aide in sampling during Haeckel's previous visit (Haeckel 1856). In Villefranche, he sought to distract his grief through work (Haeckel 1864a). He apparently worked quite hard as his stay in Villefranche was remarkably productive.

Haeckel's time in Villefranche appears to have marred by bad weather, responsible for many days of poor sampling conditions in the bay (Haeckel 1864b). This, and the fact that he was residing in Villefranche, he proudly declared himself to be the first naturalists to reside in Villefranche rather than visit from Nice (Haeckel 1864a), perhaps explains why his work consisted of largely observing living specimens rather than cataloguing new forms. Haeckel did not completely ignore radiolarians, devoting some time to observing feeding behaviour (Haeckel 1865a). He also described new species (Fig. 4). Notably, his description of one as "Protogenes primordialis" appears to be the beginning of his now discredited theory of the primitive protist cell as a form without a distinct nucleus (Haeckel 1871). However, he must have spent most of his time observing medusa, especially following their complicated developmental stages, given the large amount of data he gathered on medusa.

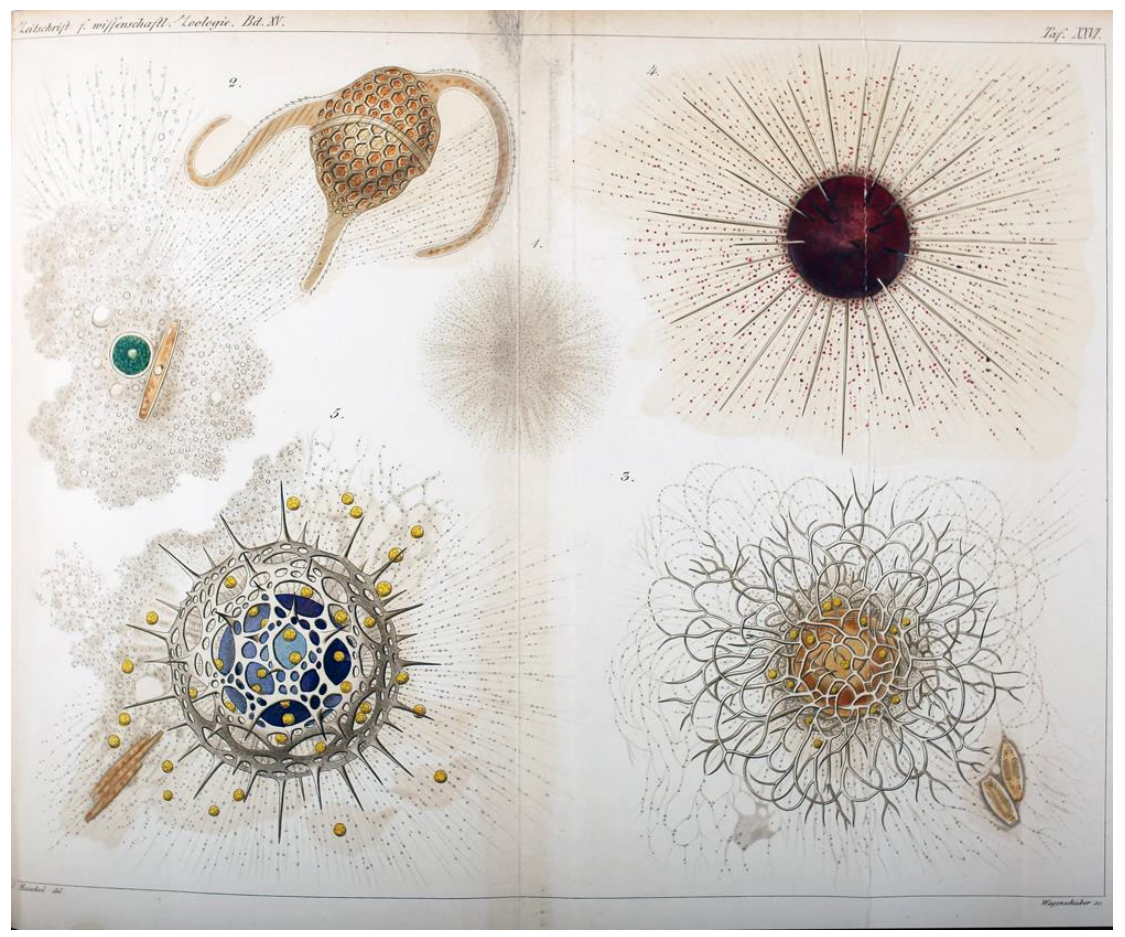

Fig. 4. The plate from Haeckel 1865a (Über den Sarcodekörper der Rhizopoden) illustrating the radiolarians observed during his 1864 visit. Fig. 1 \& 2: Protogenes primordialis 'feeding'; Fig. 3 : Acanthodesmia polybrocha; Fig. 4: Actinelius purpureus; Fig. 5: Cyrtidosphaera echinoides. The actual size of all are about $1 / 4 \mathrm{~mm}$ in longest dimension. 
Haeckel's first published illustration of medusa, describing a new species (Haeckel 1864c) came from his 1864 stay in Villefranche (Fig. 5). Remarkably, Haeckel named the new form in a sort of tribute to the local fisherman, using their term "carmarina" (Niçois for sea meat) for gelatinous plankton, as the name of the new genus, Carmarina. It would be featured later in his art book Kunstformen der Natur. Haeckel also named a new medusa shown in Figure 5, found while walking along the bay, for his deceased wife: Mitrocoma annae (Anna's headband) in a most poetic manner (Richards 2008). The small medusa would be the first of 3 species named for Anna Sethe, the second being the iconic medusa Desmonema annasethe of the Kunstformen der Natur (plate 8 below in fig. 6). The third, and last species, he named for her was a radiolarian, Dictycodon annasethe also shown in a plate in Kunstformen der Natur (plate 31 below in Fig. 8).

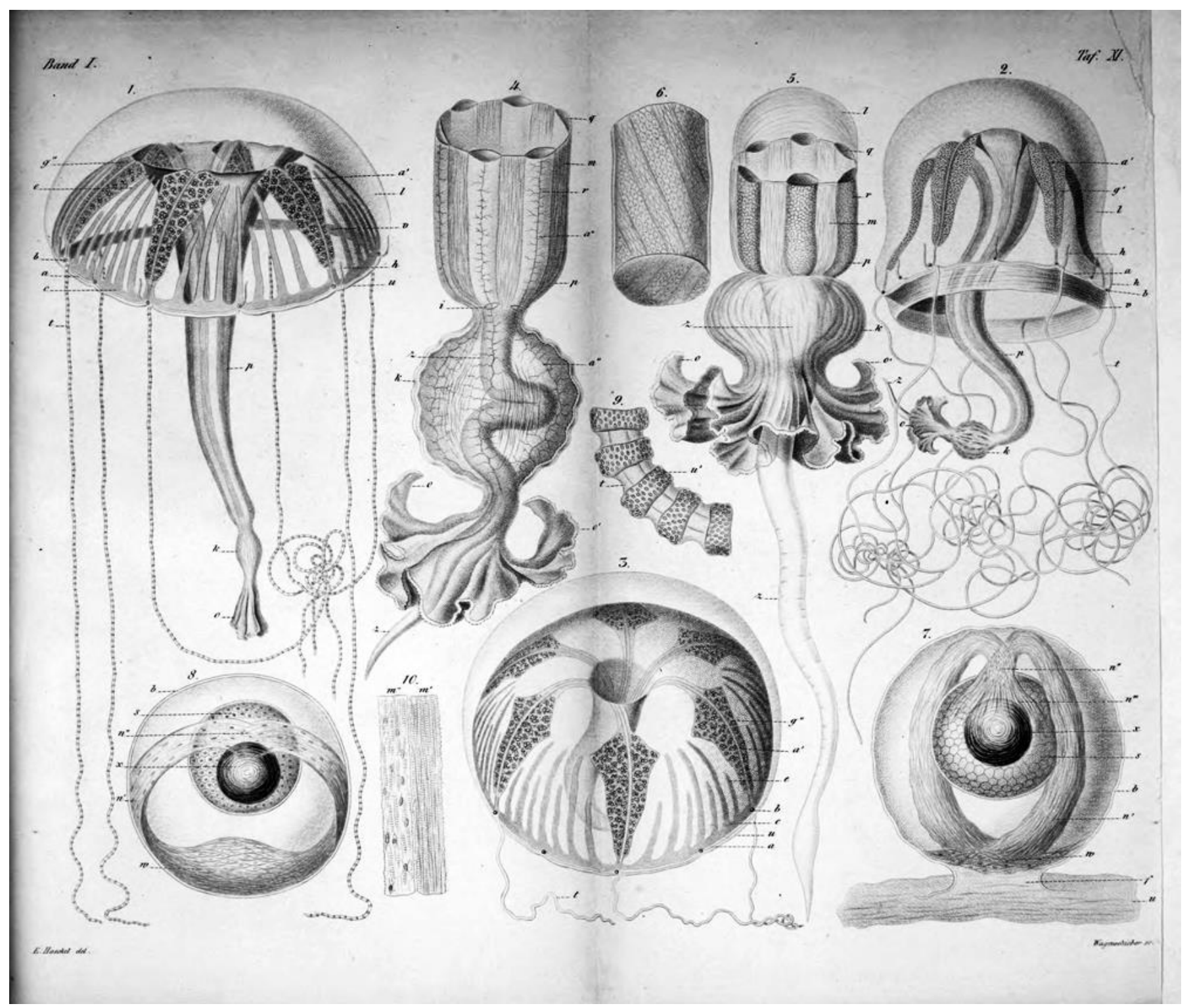

Fig. 5. Haeckel's first published illustration of a meduse: Plate 11 from Haeckel 1864c (Die Familie der Rüsselquallen, Medusae Geryonidae) Carmarina hastata. Actual size of the meduse is about $10 \mathrm{~cm}$ long. 


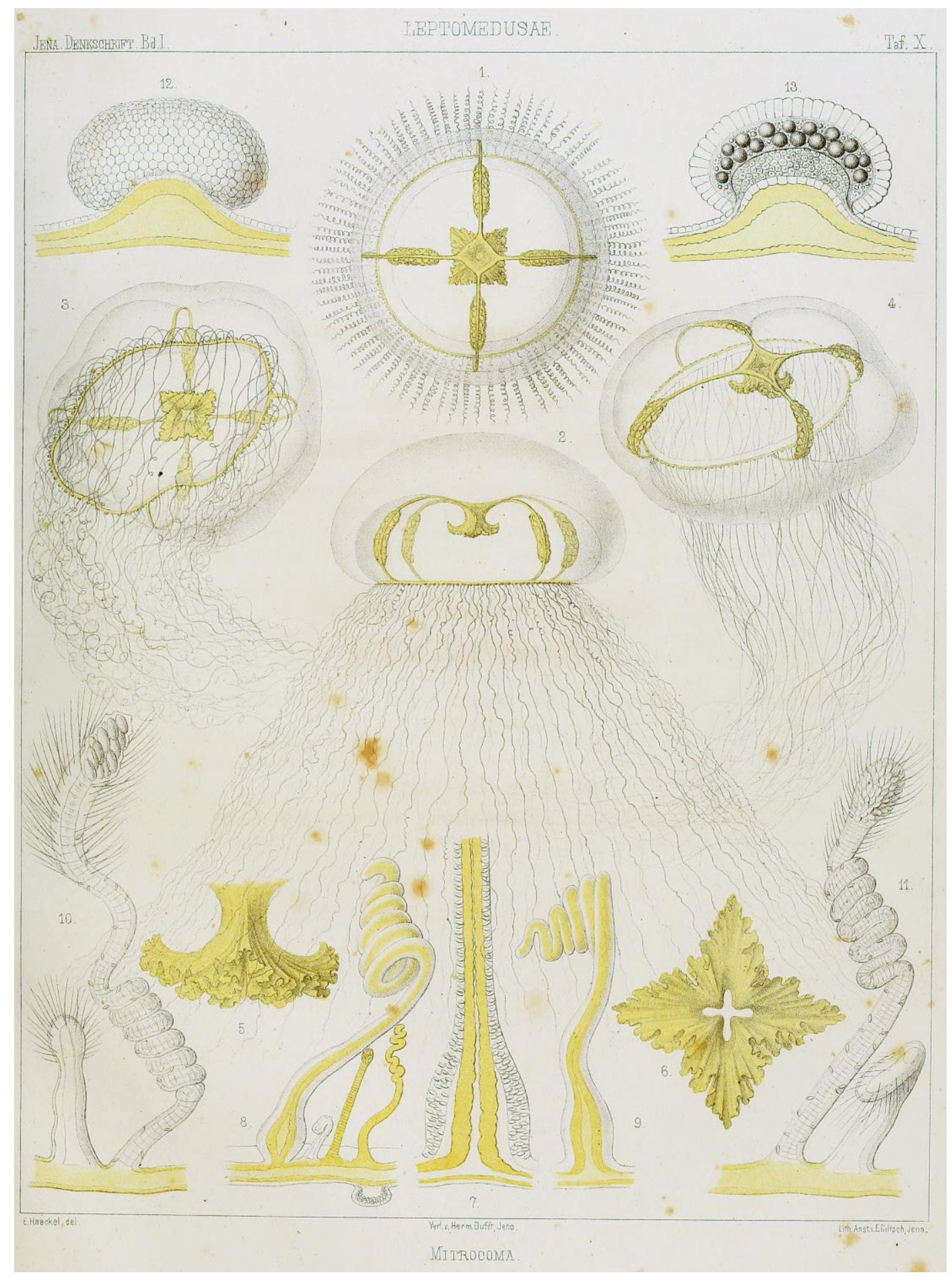

Fig. 6. One of the new medusa Haeckel found in Villefranche he named for deceased wife Anna Sethe Haeckel, Mitrocoma annae. It was the first of 3 species he named for her. The illustration is from his 1879 'System der Medusan'. The actual size of the 'bell' portion is about $4 \mathrm{~cm}$

Haeckel's publications based on his observations of medusa while in Villefranche (for less than 4 weeks!) number $4(1864 \mathrm{~b}, \mathrm{c} ; 1865 \mathrm{~b}, \mathrm{c})$ with a 5 th as a monograph combining 3 of the 4 papers (1865d). He continued his studies of medusa later in Jena with descriptions of fossil medusa (1865e, 1866, 1869a, 1874) and extant medusa (1869b). His medusa studies culminated with his Das System der Medusen $(1879,1880)$ and the deep sea medusa of the Challenger expedition $(1881,1882)$. In the Das System der Medusen, in the 1879 atlas of illustrations, 9 of the 154 species shown are stated to have been specimens from Villefranche, presumably collected or drawn during his 1864 visit. Through the years, much of his taxonomy has been revised but other parts have been validated using molecular methods (e.g. Bayha, et al. 2010). 
Haeckel's interest in medusa, unlike the radiolarians, cannot be said to have begun in Villefranche. His first 'field trip' devoted to plankton was to Helgoland (Germany) in 1854 in the company of Johnannes Müller who introduced him to "plankton fishing" (Florey 1995). According Haeckel, it was then that he discovered "the charming forms of medusa and ctenophores" (Haeckel 1893). Nonetheless, Haeckel's first detailed studies of medusa were conducted in Villefranche and only after his stay in Villefranche did he begin his ultimately very large number of studies on medusa (Fig. 7).

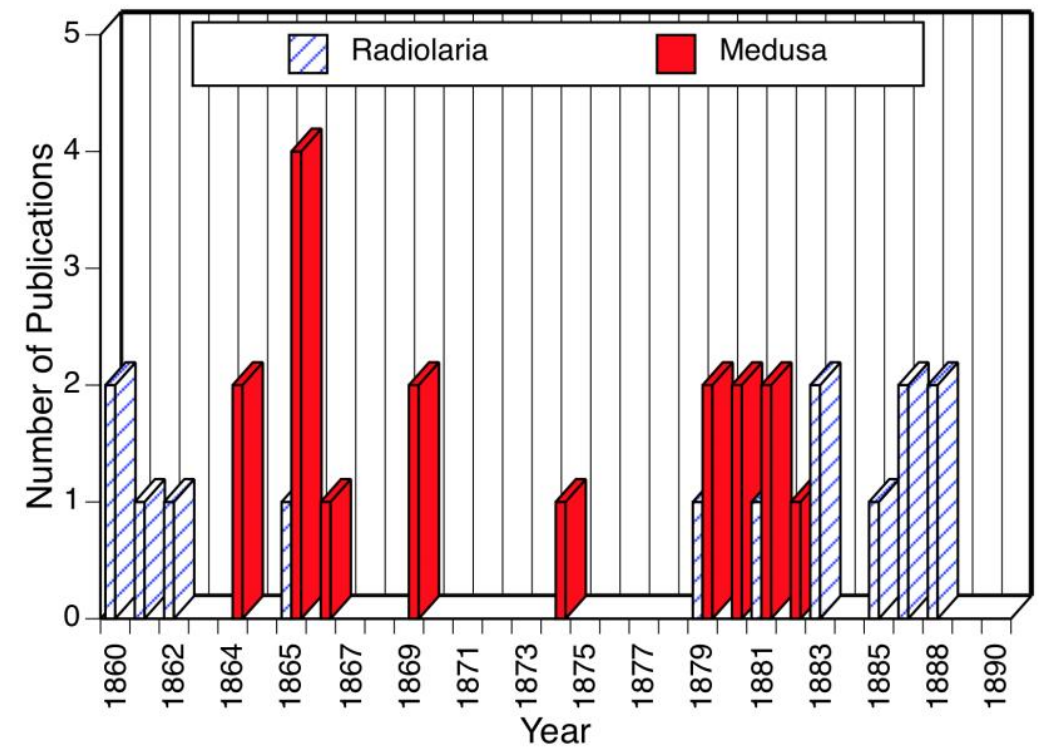

Fig. 7. Haeckel's output of publications concerning radiolarians and medusa from 1860 to 1890 based the titles given in Way's Haeckel bibliography (Way 1909). Haeckel's many publications on medusa began appearing shortly after his second visit to Villefranche. Note the apparent alternations of periods dominated by publications on one group. Haeckel's total output from 1855 to 1900 numbered 107 titles. Radiolarians and medusa accounted for 14 and 17 titles respectively, many more than any other individual groups. For example, the third most represented group was sponges with 4 titles (not shown).

\section{Radiolarians and Medusa in Haeckel's Art}

Haeckel's artwork is known almost exclusively from his Kunstformen der Natur, although it can be found in many of his monographic works such as the Challenger Reports (Williams et al. 2015). Kunstsfomen der Natur was published in 10 installments of 10 plates each from 1899 to 1904. The 100 plates had a considerable impact on the Art Nouveau movement and continue to have an impact in the fields of art and design. Furthermore, according to some, he is remembered today, even in the scientific community, more for his artwork than for his contributions to science (Williams et al. 2015). Given that Haeckel's work on radiolarians and medusa can be closely linked to his visits to Villefranche, one might ask how did radiolarians and medusa feature in his artwork? How important were they?

The relative importance of radiolarians and medusa in Haeckel's art quickly becomes apparent in surveying the 100 plates of the Kunstformen der Natur. Medusa and radiolaria feature very prominently (Fig. 8), accounting for 22 of the 100 plates. Among the 10 installments, usually both were represented. No other groups of organisms are so abundantly featured. However, a greater prominence was given to medusa to which he devoted 12 plates compared to 10 for radiolarians. One might speculate that Haeckel had a slight preference for medusa. In this regard it perhaps worth recalling that Haeckel named his house in Jena "Villa Meduse" and named two medusa, and but one radiolarian, for Anna Sethe Haeckel. 


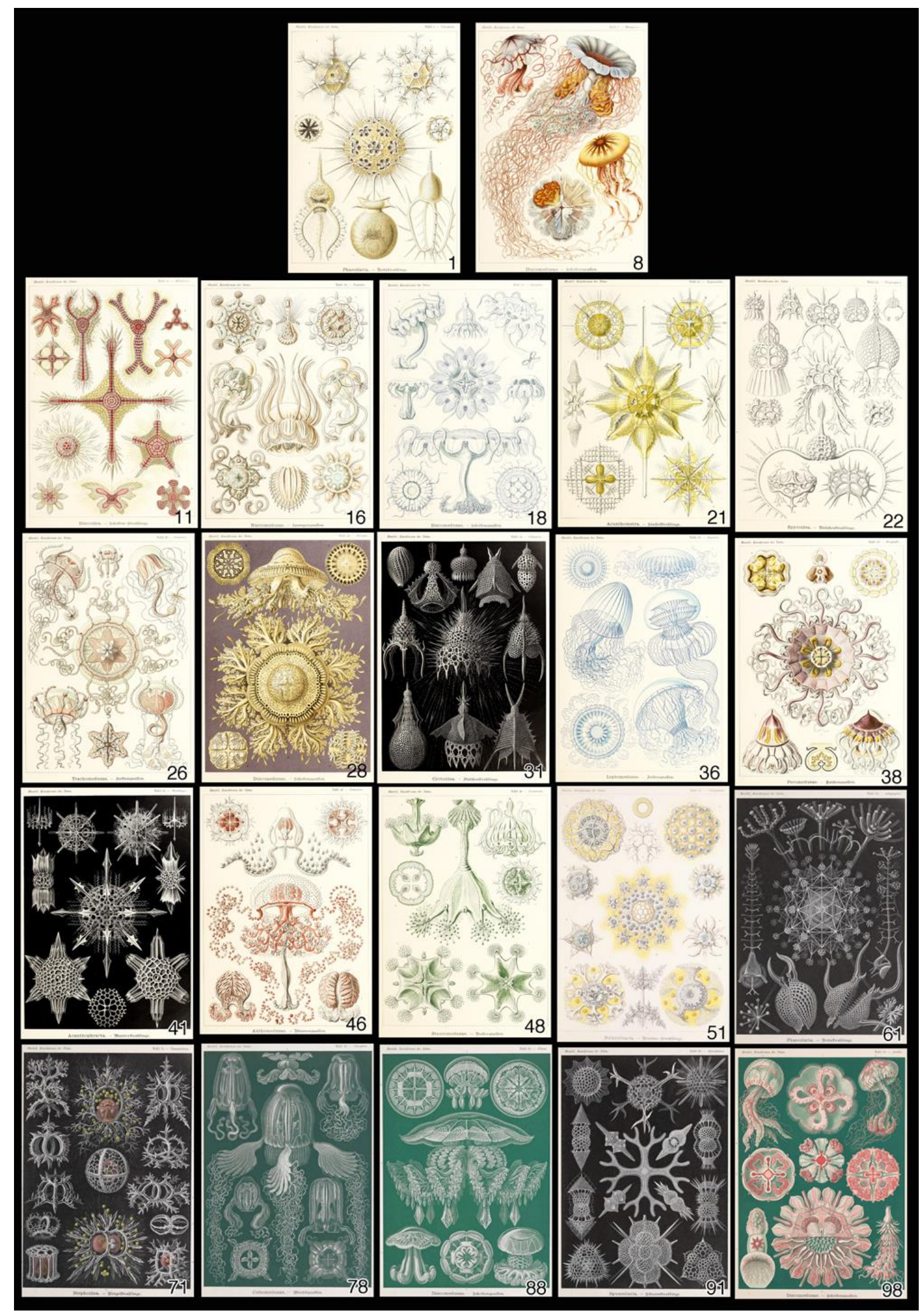

Fig. 8. The plates from Kunstformen der Natur featuring radiolarians or medusa numbered 22 out of the 100 plates. The numbers in the lower right corners denote the plate number. The book was published in installments, sets of 10 plates. Thus, the first installment contained plates 1 to 10 , the second 11 to 20 , etc.,; it can be seen then that most of the 10 installments contained both a medusa and a radiolarian plate. Plate 8 shows Desmonema annasethe, one of the two medusa species Haeckel named for his deceased wife. Plate 26 featured the medusa Carmarina hastata described from Villefranche. Plate 31 includes Dictyocodon annasethe (bottom row center), the radiolarian he named for he named for deceased wife. 
According to Richards (2009), Haeckel's illustrations in Kuntsformen der Nature have been criticized by some as being more artistic than scientific, for example artificially adding symmetry to radiolarians. In this regard it is interesting to compare an illustration from the original description to that in the Kunstsformen plate. Figure 9 shows the illustration of Dictycocodon annasethe from the original description in the Challenger Report with that in Plate 31 of the Kunstformen. Near perfect symmetry is apparent in the Kunstformen version compared to the rather approximate symmetry shown in the Challenger Report (Haeckel 1887b). Aesthetics trumped accuracy in the Kunstformen illustrations of at least some organisms. Furthermore, Haeckel's own words concerning the use of color in the Kunstformen (from Richards 2009, a translation of text from the Forward) are telling. It would appear then the Kunstformen illustrations likely should be considered as primarily artistic works rather than scientific illustrations.

I have been convinced that colored images (even of a mediocre production) are much more valuable for a vivid intuitive awareness of nature than the photograph or the simple black-and-white illustration. Indeed, a crude color sketch (if it conveys the landscape in a vivid fashion) has a deeper and more stimulating effect than the best black-and-white illustration or photographic representation. This distinction lies not only in the effect of color itself- since different individuals are sensitive in different measures- but also because the painter, as thoughtful artist, reproduces in his subjective image the conceptually articulated character of the landscape and emphasizes its essential features. The objective image of the photograph, by contrast, reproduces equally all parts of the view, the interesting and the mundane, the essential and the inessential. Thus the colored photograph, if it should be brought to perfection, will indeed never be able to replace the individually conceived and deeply felt image of the painter.
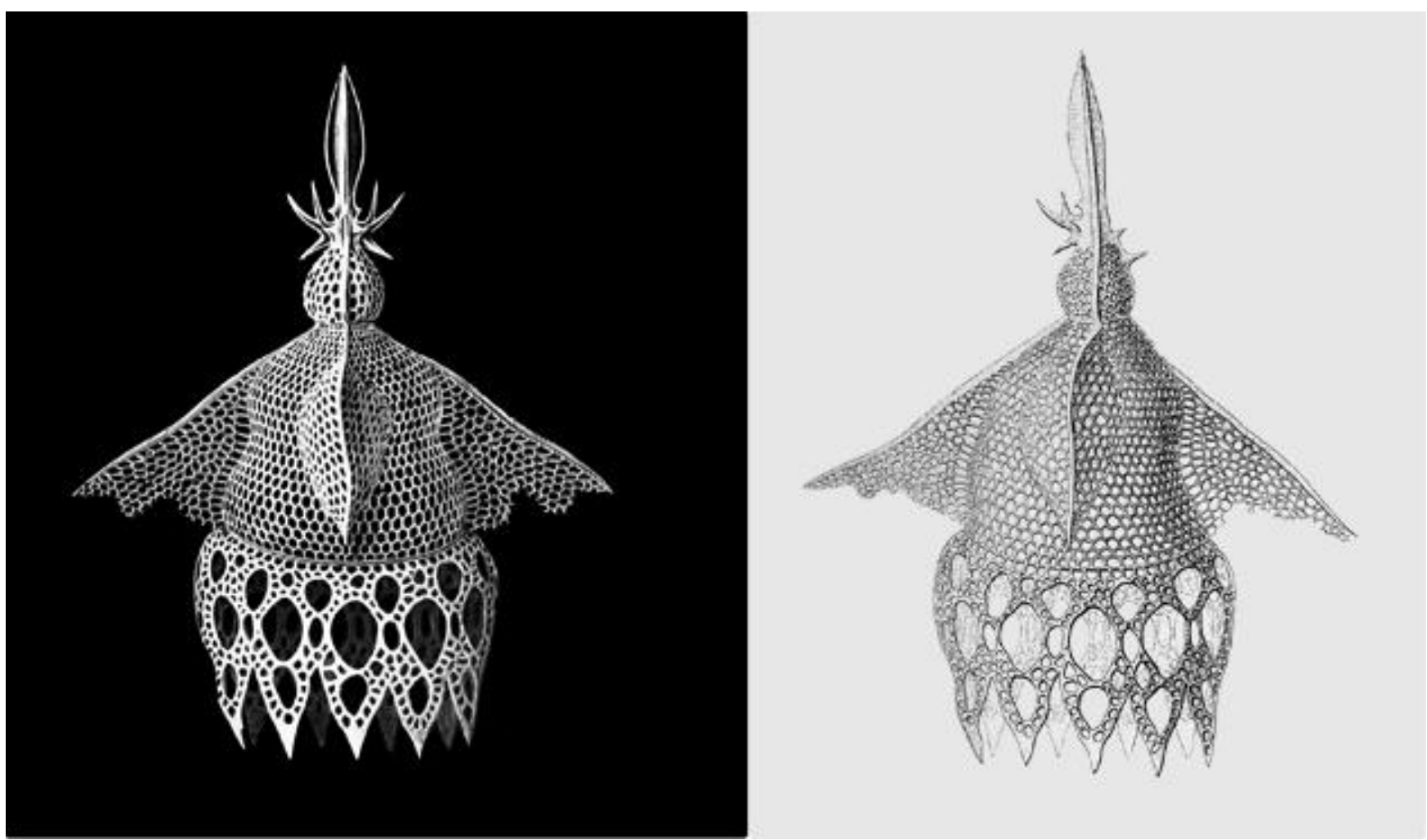

Fig. 9. Dictyocodon annasethe from Kunstformen der Natur in plate 31 (left) and from the plate 71 in the Challenger Report (right). Note the near perfect symmetry in the Kunstformen version compared to the original version. The actual size is about $1 / 5 \mathrm{~mm}$ long 
It is perhaps noteworthy that the two volume tribute to Ernst Haeckel, published a few years before his death (Schmidt 1914). and filled with laudatory texts from scientific notables was illustrated not with any of his scientific illustrations but mainly with Haeckel's landscapes. Furthermore, the last image of Haeckel in the book of remembrances is of him as an artist (Fig. 10).

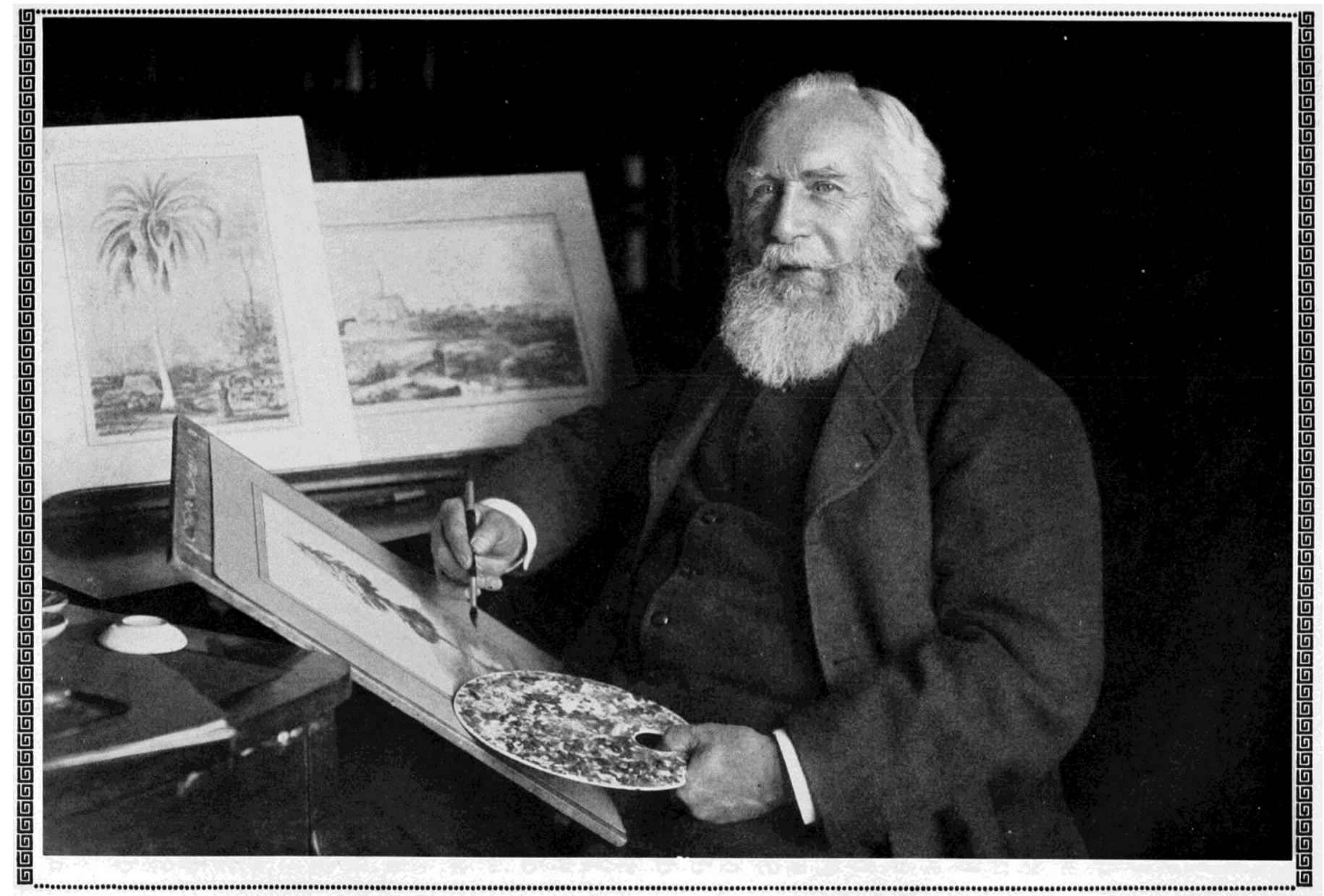

Nach einer Photographie von Alfred Bischoff, Jena. 19I4

Fig. 10. Ernst Haeckel in 1914 from the Heinrich Schmidt's 1914 tribute to Haeckel "Was wir Ernst Haeckel Verdanken". Photo by Alfred Bischoff taken in 1914.

Regardless of any scientific view, for the general public, Haeckel's illustrations are artworks. For the general public, what in Haeckel's art appears to be most popular? One manner of assessing popularity is the price of the individual plates of Kunstformen der Natur plates. Dealers in old books and prints offer for sale the individual prints. Presumably the plates were printed in about equal numbers so that price differences among the plates should reflect differences in demand more than supply. One dealer offering individual plates for many years now is Stefan Wulf of Berlin. His 2019 catalogue (Wulf 2019) includes all the plates.

In Wulf's catalogue, the prices of the Kunstformen plates vary considerably, from $\$ 25$ to $\$ 250$, with the highest price asked for the plate 8 of the medusa Desmonema annasethe. One naturally assumes that the multi-colored plates fetch a higher price than the mono-chromatic plates, regardless of subject, and indeed the average prices are $\$ 91$ and $\$ 49$, respectively. Still, among the multicolored plates, the medusa plates average $\$ 91$ and the radiolarian plates $\$ 61$. Thus, it appears that, based on prices, the medusa plates are more popular than the radiolarian plates. Are the medusa and radiolarian plates overall more appreciated, based on price? The average price of the medusa and radiolarian plates is $\$ 71$ compared to $\$ 63$ for the other subjects. It appears then that is a higher demand for plates with medusa or radiolarians than for other subjects. 


\section{Conclusion: Villfranche \& Haeckel}

As a final note concerning the importance of Haeckel's visit to Villefranche, it does appear the subjects linked to his stays in Villefranche, the radiolarians and medusa, were to the most popular with Haeckel himself, among the many zoological topics he studied, given the number of publications he ultimately devoted to them (Fig. 5). His medusa and radiolarian artwork, compared to his other subjects, appear to be the most popular with today's general public based on the asking prices for Haeckel's artworks. Thus, his major scientific and artistic legacies, both of which are considerable, are intimately linked to Villefranche. Despite the apparent links, Haeckel did not return to Villefranche until late in his life, just a few years before his death in 1919. He visited his former student Michael Davidoff at the Russian Zoological Station in Villefranche while attending the 1910 opening of the Oceanographic Museum (Davidoff 1914). One can only speculate that perhaps Villefranche was also intimately linked to his grieving for Anna Sethe.

\section{Acknowledgements}

Encouragement was kindly provided by Robert J. Richards and Marie-Christine Maurel. The comments of David Montagnes on earlier drafts resulted in considerable improvement. However, I retain full responsibility for all errors of fact and interpretation.

\section{References}

Aita, Y., Suzuki, N., Ogane, K., Sakai, T., Lazarus, D., Young, J., \& Tanimura, Y. 2009. Haeckel Radiolaria Collection and the HMS Challenger Plankton Collection. Joint Haeckel and Ehrenberg Project: reexamination of the Haeckel and Ehrenberg microfossil collection as a historical and scientific legacy. Japan National Museum of Nature and Science, Monograph, Tokyo, 40, 35-45.

Bass, D., Moreira, D., López-García, P., Polet, S., Chao, E. E., von der Heyden, S., Pawlowski, J. Cavalier-Smith, T. 2005. Polyubiquitin insertions and the phylogeny of Cercozoa and Rhizaria. Protist, 156:149-161.

Bayha, K. M., Dawson, M. N., Collins, A. G., Barbeitos, M. S., \& Haddock, S. H. 2010. Evolutionary relationships among scyphozoan jellyfish families based on complete taxon sampling and phylogenetic analyses of $18 \mathrm{~S}$ and $28 \mathrm{~S}$ ribosomal DNA. Integrative and Comparative Biology, 50: 436-455.

Biard, T., Bigeard, E., Audic, S., Poulain, J., Gutierrez-Rodriguez, A., Pesant, S., Stemmann, L., Not, F. 2017. Biogeography and diversity of Collodaria (Radiolaria) in the global ocean. The ISME Journal, 11: 1331-1344.

Davidoff, M. 1914. Was für mich Haeckel's "Natürliche Schôpfungsgeschitchte" bedeutet. in Schmidt, H. 1914. Was wir Ernst Haeckel Verdanken. 2 volumes, Verlag Unesma, Leipzig, v.1, pp 319-322.

Dolan, J. R., Ciobanu, M., \& Coppola, L. (2019). Past President's Address: Protists of the Mesopelagic and a Bit on the Long Path to the Deep Sea. Journal of Eukaryotic Microbiology, in press.

Egerton, F. N. 2013. History of ecological sciences, part 47: Ernst Haeckel's ecology. ESA Bulletin, 94: 222-244. https://esajournals.onlinelibrary.wiley.com/doi/pdf/10.1890/0012-9623-94.3.222

Florey, E. 1995. Highlights and sidelights of early biology on Helgoland. Helgolander Meeresunters. 49:77-101.

Grattepanche, J. D., Walker, L. M., Ott, B. M., Paim Pinto, D. L., Delwiche, C. F., Lane, C. E., Katz, L. A. 2017. Microbial diversity in the eukaryotic SAR clade: Illuminating the darkness between morphology and molecular data. BioEssays, 40:1700198.

Haeckel, E. 1856. Ernst Haeckel an Charlotte und Carl Gottlob Haeckel, Nizza, 1. - 5. Oktober 1856. https://haeckelbriefwechsel-projekt.uni-jena.de/de/document/b_44161

Haeckel, E. 1862. Die Radiolarien (Rhizopoda Radiaria). Eine Monographie. Vol. 572p, Vol. 2 Atlas of 35 plates. G. Reimer Verl., Berlin.

Haeckel 1864a. Ernst Haeckel an Charlotte und Carl Gottlob Haeckel, Villafranca , 21. März 1864. https://haeckelbriefwechsel-projekt.uni-jena.de/de/document/b_38572 
Haeckel, E. 1864b. Beschreibung neuer craspedoter Medusen aus dem Golfe von Nizza. Jenaische Zeitschrift für Medicin und Naturwissenschaft 1:325-342.

Haeckel, E. 1864c. Die Familie der Rüsselquallen (Medusae Geryonidae). Jenaische Zeitschrift für Medicin und Naturwissenschaft 1:435-469.

Haeckel, E. 1865a. Über den Sarcodekörper der Rhizopoden. Z. Wiss. Zool. 15:342-370.

Haeckel, E. 1865b. Über eine neue Form des Generationswechsels bei den Medusen und über die Verwandtschaft der Geryoniden und Aginiden. Monatsber. Akad. Wiss. Berlin 1865: 85-94.

Haeckel, E. 1865c. Die Familie der Rüsselquallen (Medusae Geryonidae) [Fortsetzung und Schluß]. Jenaische Zeitschrift für Medicin und Naturwissenschaft 2 (1865/66):93-322.

Haeckel, E. 1865d. Beiträge zur Naturgeschichte der Hydromedusen. Erstes Heft: Die Familie der Rüsselquallen (Geryonida). A. Engelmann, Leipzig [compilation of Haeckel 1864a,b,c].

Haeckel, E. 1865. Über fossile Medusen. Z. wiss. Zool. 15: 504-514, Taf. 39.

Haeckel, E. 1866. Über zwei neue fossile Medusen aus der Familie der Rhizostomiden. Neue Jb. Mineralogie 1866:257-292.

Haeckel, E. 1869a. Über die fossilen Medusen der Jurazeit. — Z. wiss. Zool. 19: 538-562.

Haeckel, E. 1869b. Über die Crambessiden, eine neue Medusenfamilie aus der Rhizostomen- Gruppe. Z. wiss. Zool. 19: 509-537, Taf. 38, 39.

Haeckel, E. 1871. Nachträge zur Monographie der Moneren. Jenaische Zeitschrift für Medicin und Naturwissenschaft (1870/71):23-44.

Haeckel, E.1874. Über eine sechszählige fossile Rhizostomee und eine vierzählige fossile Semaeostomee. Vierter Beitrag zur Kenntnis der fossilen Medusen. Jenaische Zeitschrift für Medicin und Naturwissenschaft (N. F. 1) 8: 308-330, Taf. 10, 11.

Haeckel, E. 1879. Das System der Medusen. Erster Teil einer Monographie der Medusen: Craspedoten (I. Bd. der Denkschriften der Med. Naturwiss. Gesellschaft zu Jena) Jena 1879, G. Fischer. 360 p., 20 plates.

Haeckel, E. 1880. Das System der Medusen. Zweiter Teil einer Monographie der Medusen: Ascraspeden. Jena 1880, G. Fischer. 312 p., 20 plates.

Haeckel, E. 1881 Monographie der Medusen. Zweiter Theil. Erste Hälfte: Die Tiefsee-Medusen der Challenger-Reise. Zweite Hälfte: Der Organismus

der Medusen. Zweiter Teil einer Monographie der Medusen. (II Bd. der Denkschriften der Medizinisch - Naturwiss. Gesellschaft zu Jena) Jena 1181, G. Fischer. 250 p 32 plates.

Haeckel, E. 1882. Report on the deep-sea Medusae dregded by H.M.S. Challenger during the years 1873-1876. Reports of the Scientific Results of the Voyage of H.M.S. Challenger 1873-76, Zoology 12: 1-154, 32 plates.

Haeckel, E. 1887a. Report on the Radiolaria collected by HMS Challenger during the years 1873- 76. First part. Porulosa. (Spumellaria and Acantharia). Reports of the Scientific Results of the Voyage of H.M.S. Challenger 187376. Zoology 18: 1-888.

Haeckel, E. 1887b. Report on the Radiolaria collected by HMS Challenger during the years 1873- 76. Second part. Osculosa (Nasellaria and Phaeodaria) Reports of the Scientific Results of the Voyage of H.M.S. Challenger 187376. Zoology 18: 889-1893.

Haeckel, E. 1887c. Die Radiolarien (Rhizopoda Radiaria). Eine Monographie. 2: Grundriß einer allgemeinen Naturgeschichte der Radiolarien. G. Reimer Verl., Berlin 2: 1-248, 64 plates.

Haeckel, E. 1888a. Die Radiolarien (Rhizopoda Radiaria). Eine Monographie. 3: Die Acantharien oder actipyleen Radiolarien. G. Reimer Verl., Berlin 3:1-27, 12 plates.

Haeckel, E. 1888b. Die Radiolarien (Rhizopoda Radiaria). Eine Monographie. 4: Die Phaeodarien oder cannopyleen Radiolarien. G. Reimer Verl., Berlin 4: 1-25, 30 plates

Haeckel, E. 1893. Plankton studies: a comparative investigation of the importance and constitution of the pelagic fauna and flora (translated by G.W. Field). Report of the U.S. Commissioner of Fish and Fisheries, for 1889 to 1891, pages 565-641. 
Haeckel, E. 1899-1904. Kunstformen der Natur. Bibliographisches Instituts.

Kachovich, S., Sheng, J., Aitchison, J. C. 2019. Adding a new dimension to investigations of early radiolarian evolution. Scientific Reports, 9:6450.

Lazarus, D. 2014. The legacy of early radiolarian taxonomists, with a focus on the species published by early German workers. Journal of Micropalaeontology, 33:3-19.

May, W. 1909. Ernst Haeckel, Versuch einer Chronik seines. Lebens und Wirkens.

Müller, J., 1858. Über die Thalassicollen, Polycystinen und Acanthometren des Mittelmeeres. Abh. Königl. Preuß. Akad. Wiss. Berlin, 1858 : 1-62

Otis, L. 2007. Müller's Lab. Oxford University Press.

Richards, R.J. 2008. The Tragic Sense of Life: Ernst Haeckel and the Struggle over Evolutionary Thought. University of Chicago Press.

Richards, R.J. 2009. The tragic sense of Ernst Haeckel: his scientific and artistic struggles. in Kort, P. Hollein, M. (eds) Darwin and the Search for Origins, Art Stock Books Ltd.

Schmidt, H. 1914. Was wir Ernst Haeckel Verdanken. 2 volumes, Verlag Unesma, Leipzig.

Williams, Peter le B., Evans, Dylan W., Roberts, David J., Thomas, David N. 2015. Art Forms from the Abyss - Ernst Haeckel's Images from the HMS Challenger Expedition. Prestel, Munich.

Wulf, S. 2019. Ernst Haeckel's Artforms in Nature: A Catalogue of all 100 plates, 33 suites and 2 fine copies. Antiquariat Stefan Wulf, Berlin. https://www.rarebooksberlin.de/fileadmin/haeckel_artforms.pdf 